Keywords:

Tree planting technique

Growth

Survival

Wildlings

Histórico:

Recebido 20/07/2016

Aceito 29/08/2016

Palavras chave:

Técnicas de plantio

Crescimento

Sobrevivência

Mudas de regeneração natural

Correspondência: thomaschroder@gmail.com
Thomas Schroder', Anna Paula Lora Zimmermann', Lílian Daniel Pereira', Noé dos Santos Ananias Hofiço², Dilson Sousa Rocha Júnior ${ }^{3}$, Frederico Dimas Fleig', Evandro Alcir Meyer'

\section{USING BARE-ROOT AND ROOTSTOCK SEEDLINGS FROM NATURAL REGENERATION OF CEDRELA FISSILIS}

ABSTRACT: The success of forest creation relies on seedling availability and quality. The aim of this research is to assess the possible use of rootstock and bare-root seedlings of Cedrela fissilis obtained from natural regeneration for direct field planting. We used Generalized Linear models to assess survival and Hierarchical Models to assess height growth over one year after planting. Initial root-collar diameter (RCD) and treatment (rootstock or bare-root) affected survival and growth. Rootstock and larger seedlings presented higher levels of survival and growth. Higher seedling quality in the rootstock treatment is due to higher water stress tolerance. Rootstock seedlings with more than $\mathrm{I} \mathrm{cm}$ of initial RCD had over $80 \%$ of survival probability, while small bare-root seedlings had mean survival probability as low as $20 \%$. Rootstock seedlings grew as much as fourfold more than bare-root. Using natural regeneration of $C$. fissilis as a source of rootstock seedlings may be a cheap alternative for forest restoration and enrichment planting projects.

\section{UTILIZAÇÃO DE MUDAS DE RAIZ NUA E MUDAS DE TOCO PROVENIENTES DA REGENERAÇÃO NATURAL DE CEDRELA FISSILIS}

RESUMO: O sucesso da implantação de florestas depende da disponibilidade e da qualidade de mudas. O objetivo desta pesquisa é avaliar a possibilidade do uso de mudas de toco e mudas de raiz nua de Cedrela fissilis obtidas de regeneração natural para plantio à campo. Nós usamos Modelos Lineares Generalizados para avaliar sobrevivência e Modelos Hierárquicos para avaliar crescimento em altura durante um ano após o plantio. O diâmetro do colo (DC) inicial e tratamento (mudas de raiz nua ou de toco) afetaram a sobrevivência e o crescimento. Mudas de toco e mudas com maior DC inicial apresentaram maiores probabilidades de sobrevivência e maior crescimento. A melhor qualidade de mudas no tratamento de mudas de toco é devido à maior tolerância ao stress hídrico. Mudas de toco com DC inicial maior que $\mathrm{I} \mathrm{cm}$ tiveram probabilidade de sobrevivência acima de $80 \%$, enquanto mudas de raiz nua pequenas tiveram probabilidade de sobrevivência média de $20 \%$. As mudas de toco cresceram quatro vezes mais que mudas de raiz nua. A utilização da regeneração natural de $C$. fissilis como fonte de mudas de toco pode ser uma alternativa barata para projetos de restauração florestal e plantios de enriquecimento. 


\section{INTRODUCTION}

Artificial regeneration is the process to grow forests through anthropic energy input. This type of forest regeneration is used to produce forests for environment restoration (CAMPOE et al. 20 I0; CAMPOE et al. 20I4), enrichment of natural forests (KETTLE 2009; NAVARROCERRILLO et al. 20I I; SCHWARTZ et al. 20I3) or to constitute highly productive monocultural plantations (DESROCHERS; TREMBLAY 2009). The costs of artificial regeneration are associated with site slope, access to site, human labor cost, seedling availability and the need for post-planting competition control (BIRCH et al. 2010; CAMPOE et al. 2010). Seedlings with high quality and fast initial growth decrease artificial regeneration costs by reducing competition control costs (MCNABB; SCHAAF 2005) and increase the financial yield from the forest by reducing the time span between planting and logging trees.

Rootstock seedlings may be the best definition for bare-root seedlings with the shoot pruned close to the stump (DESROCHERS; TREMBLAY 2009). Another term used is stump planting (EVANS 1992), but this does not clearly state what constitutes the seedling, since almost the whole root system is still attached to the plant. This type of seedling has been successfully used in southeastern Asia for teak plantations, as well as for other species. It is mostly used by smallholders due to low cost (ICHIWANDI et al. 2009), because most of the seedlings are obtained from natural regenerating teak saplings. There have been trials with this method in North America (SOUTH, 1996; DESROCHERS; TREMBLAY, 2009) with mixed success (SOUTH; DONALD, 2002), due to lower sprouting capacity of coniferous species.

The method of obtaining rootstock seedlings allows the transportation of this propagation material for longer distances and may even allow storage for restricted time spans (DESROCHERS; TREMBLAY 2009). This is made possible by the very small shoot to root ratio $(S: R)$, which is a desirable seedling feature. $S: R$ greater than three is known to cause very low tolerance drought (GROSSNICKLE 20I2). For coniferous, which are drought resistant species, the method of rootstock seedlings may only decrease the total height (SOUTH; DONALD, 2002) of the seedling, reducing its competitive ability.

One source of cheap material for obtaining rootstock seedlings is the use of natural regeneration from established forests (VIANI; RODRIGUES, 2009). The use of natural regeneration is a common procedure for teak plantations in southeastern Asia (HODGE et al., 2009) and has also been tested in Brazil (VIANI and RODRIGUES 2009; VIANI et al. 2012). If the seedlings are obtained from nearby forest areas, they are prone to have a greater adaptability to the environment (KETTLE 2009), in addition to the fact that these seedlings have already been through a selection process during establishment on the forest floor.

The success of forest plantations relies on the acceptance of the landowner of the species being used (CHAZDON 2008; KETTLE 2009). Landowners tend to prefer to plant trees with wood of high commercial value or with edible fruits, since these characteristics are readily related to some economic yield (CHAZDON 2008; HARRISON et al. 2008). In this context, Cedrela fissilis Vell. (Meliaceae) (SMITH JR 1960), a light demanding deciduous species, is one of the few species from Brazil with high sawn timber international market value. Furthermore, it has high sprouting ability, making it ideal for planting trials with small and even large landowners. C. fissilis, like many Meliaceae, is attacked by shot borers, limiting its use in large scale plantations. The genetic pool of this species has been eroded due to selective logging, thus developing suitable techniques for collection and establishment of $C$. fissilis seedlings are key for conservation and silviculture of this tree species.

The objective of this work was to test the planting of $C$. fissilis rootstock and bare-root seedlings obtained from natural regenerating saplings in southern Brazil. More specifically, we aimed to compare seedling survival, number of leaves (as a proxy to seedling vitality) and growth between bare-root and rootstock seedlings at different sizes during a full growing season.

\section{METHODS}

\section{Experimental design}

The study site is located in the Central Depression of Rio Grande do Sul, Brazil. The mean annual temperature is $25^{\circ} \mathrm{C}$, with monthly minimum average temperature $18^{\circ} \mathrm{C}$, and maximum of over $30^{\circ} \mathrm{C}$ in February. Mean annual rainfall is $180 \mathrm{~cm}$, with no dry season, although water deficits are usual during summer (HELDWEIN et al. 2009). The soils of the region are mainly acrisols with variations caused by the position in the relief, as soils closer to water courses show signs of oxidation (DALMOLIN; PEDRON, 2009).

In September 2012, 50 saplings of $C$. fissilis were collected from a nearby forest site by uprooting the plants. As it was the beginning of the growing season, saplings already had 2-8 leaves. As a light demanding 
species, most of the $C$. fissilis saplings were found close to forest edges. On the same day, these saplings were taken to an experimental field at Universidade Federal de Santa Maria. There the bare-root saplings were weighed and visually paired according to morphological similarities such as size and apparent vitality. In each pair one of the seedlings had its shoot pruned, leaving about $10 \mathrm{~cm}$ of the shoot, excessive and bent roots were also pruned, generating the rootstock seedlings. The leaves of the bare-root seedlings were cut in half as a way to reduce water loss. Seedlings were planted in open field with I $\mathrm{I}$ I m regular spacing. Each pair of seedlings was planted side by side as to reduce spatial variation in the experiment. Heavy irrigation was carried out after planting and two days later as a means to eliminate the air around the roots.

Measurements began 15 days after planting. Until the $45^{\text {th }}$ day after planting the number of sprouts in the rootstock seedlings was recorded, at this point only the most vigorous sprout in each plant remained, as the others were manually pinched off. Measurements in the rootstock and bare-root seedlings continued for every month until October 20I3. Root-collar diameter (RCD), shoot height, number of leaves and main shoot survival were obtained from each plant. Measurements were suspended during winter of 2013 as plants had no leaves and did not grow during this season.

\section{Data analysis}

The data were treated as a complete randomized experiment. Means of the initial observed variables from bare-root and rootstock seedlings were compared through $t$ test, as a way to test the efficiency of the visual pairing. Time, treatment (bare-root or rootstock) and seedlings initial diameter were considered the factors influencing the seedling development. For model development we divided the seedlings into three size classes: RCD smaller than I cm, between I and $2.5 \mathrm{~cm}$ and larger than $2.5 \mathrm{~cm}$. Number of leaves and sprouts were regressed using generalized linear models considering a Poisson distribution using a Log link function. Seedling survival had the same treatment but considering a Binomial distribution and Logit link. Height increment was modeled using full factorial parsimonious model through stepwise regression or manual elimination of non-significant coefficients, considering the data nested in each tree. The developed linear mixed model had its error correlation and heteroscedasticity matrix chosen by the visual analysis of a scatter plot of the residuals against the fitted values. The data were analyzed using $R$ software (R CORE TEAM 20I3).

\section{RESULTS AND DISCUSSION}

We used saplings of RCD ranging from 0.3 to 4.2 $\mathrm{cm}(1.9 \pm 0.9)$ (mean \pm standard deviation, respectively), corresponding to a total weight range from 19 to $907 \mathrm{~g}$ $(185 \pm 181)$. This is a large range for a seedling trial, since most of the nursery seedlings produced seldom has RCD larger than $1.5 \mathrm{~cm}$. We found no difference between pruned and whole seedlings groups for the initial values of RCD $(p=0.56)$, initial height $(p=0.96)$ neither for seedling total weight $(p=0.70)$. Therefore, the visual pairing of plants had no influence on this experiment.

The rootstock seedlings had buds profusely sprouting 15 days after planting. Over $90 \%$ of the seedlings had buds already sprouting at this time. This fast response is due to the sprouting capacity of the studied species, but especially due to the irrigations that were carried out alongside with the rainy season in which the seedlings were planted. High soil humidity and rainfall (or irrigation) avoid great water losses by the seedlings and also eliminate the air around the roots remaining from the planting operation, creating a tight root-soil interface faster than in drier environments, thus increasing survival. Despite this rapid response to treatment, the number of sprouts tended to decrease in the time after planting (Figure I). Therefore, the developed model had time, quadratic time and diameter class as predictors of the numbers of sprouting buds. This model did not have an intercepted and had all significant coefficients $(p<0.01)$, reducing the null variance by over $70 \%$.

The decrease of sprouting buds over time is due to the development of the primary meristems and initial height growth. These primary meristems are known to produce auxin, which inhibits bud sprouting and the growth of other primary meristems in lower parts of plants (ZIMMERMANN; BROWN, 197I) as long as the sap flux between roots and the primary meristem is fairly solid (BORCHERT; TOMLINSON, 1984). Hence, it is natural that as soon as there is at least one established and growing shoot, other shoots or sprouting buds may die with time. The number of sprouting buds was larger in the seedlings with smaller RCD. Smaller seedlings that have less stiff stems are ontogenetically younger, which makes them a better material for vegetative reproduction. Therefore, these seedlings are more prone to developing new roots and sprouts. The difference between the number of sprouts of smaller and larger seedlings decreases with time. Although the smaller seedlings are able to produce faster for shoot sprouts, it forces for a higher selection between sprouts, thus, along time any difference in sprouting tends to be eliminated. 


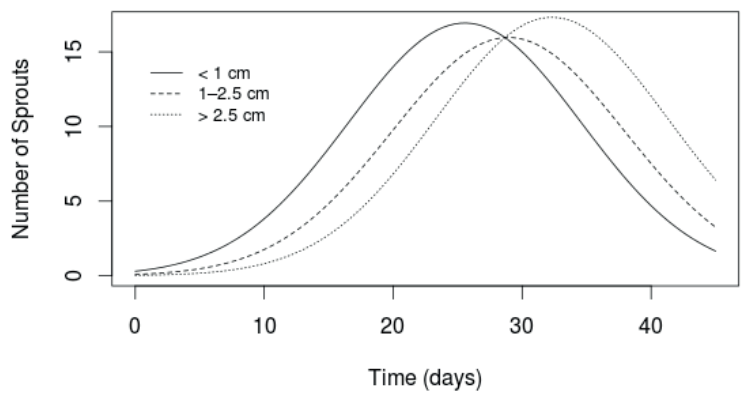

FIGURE I Number of sprouting buds of the rootstock seedlings of Cedrela fissilis for different rootcollar diameters.

High survival rates in the field is the most desirable characteristic for seedlings. This characteristic must be assessed in a considerable time span. Our seedlings had good survival rates for the initial months due to irrigation and high water availability in the soil. The model developed to predict survival probability reduced null variance by almost $25 \%$. Along time large differences between treatments and seedling size appeared. Larger seedlings had much higher one-year survival rates (over $80 \%$ ) when they were treated in the rootstock (Figure 2). Large bare-root seedlings had survival rate probability as low as $40 \%$. Large seedlings have higher survival rates (MCNABB; SCHAAF, 2005; SIDHU; DHILLON, 2007). However, these survival rates are based on the main shoot survival. Many bare-root seedlings shoots died but the seedling survived through sprouting in parts of the stem closer to the ground. In this sense, it appears to be a natural process of top pruning. Therefore transforming bare-root into rootstock seedlings by top pruning is a technique which should accelerate a natural process by as much as one year (DESROCHERS; TREMBLAY, 2009), reducing the time of weeding and thus costs with forest creation.

Bare-root seedlings of $C$. fissilis smaller than $I \mathrm{~cm}$ are very unviable, never having survival rate probability greater than $60 \%$. Since they have extremely low survival rate probability, the production of small seedlings of this species must be made with containers. The higher survival rate of the rootstock seedlings (DONOSO et al. 2009) is due to a reduced evapotranspiration from leaves and stem, making the seedling less prone to die during water limited periods. Moreover, there are morphological adaptations at leaf level to the outfield environment, since the saplings are collected in environments with different degrees of shading. The rootstock seedlings have all leaves adapted in outfield conditions, whereas in bare-root seedlings the initial photosynthesis occurs in leaves that were not produced for these environmental conditions. This treatment may be considered a method for a drastic reduction of the shoot to root ratio, which is a desirable seedling condition.
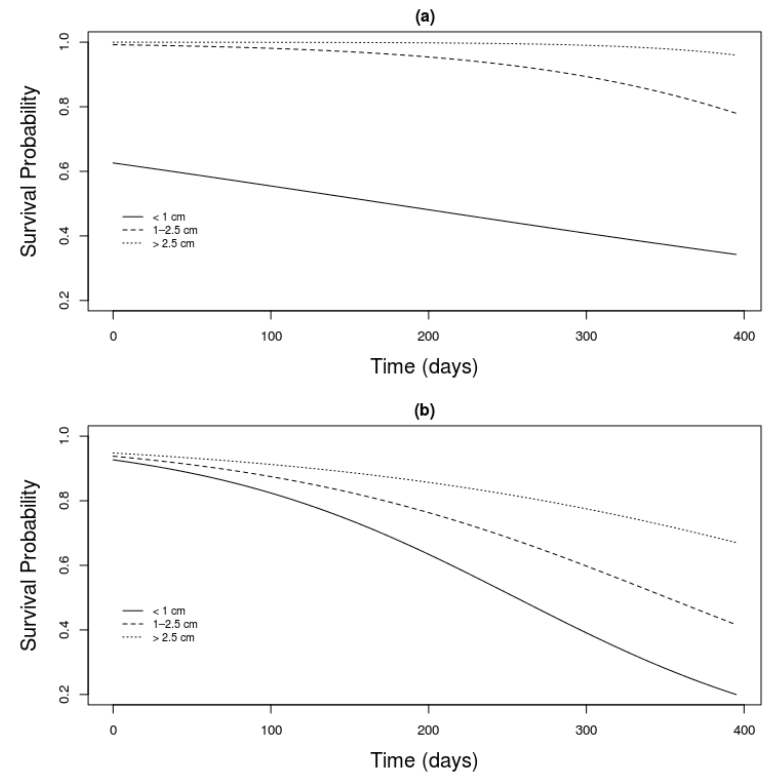

FIGURE 2 Main shoot survival probability for rootstock (a) and bare-root (b) seedlings of Cedrela fissilis. The level refers to differences in root-collar diameters of seedlings smaller than $\mathrm{I} \mathrm{cm}$ in diameter at soil level (continuous line), between I and $2.5 \mathrm{~cm}$ (broken line) and larger than $2.5 \mathrm{~cm}$ (dotted line).

Since it is a deciduous species, C. fissilis leaf production during a growing season is fundamental for growth in the same season, and for carbohydrate accumulation for early growth and new leafs development in the next growing season (YOSHIMURA, 20I0). In this sense, results may be influenced by primary production of the saplings in the growing season prior to its lifting, once our data is limited to observations in one growing season. However, we do believe that seedling pairing was effective in eliminating this tendency. Our model included time, initial diameter and treatment as variables to control leaf production. Larger seedlings produced more leaves as they had more carbohydrate reserves in its roots and stems. Nevertheless, the most interesting result is related to the treatment effect.

Since bare-root seedlings had not had all their leaves removed, they had a head start in photosynthetic surface, but those leaves were not adapted to the full light environment (YOSHIMURA, 20I0). In less than a hundred days after planting rootstock, seedlings already had more leaves than bare-root. It seems that the sap flux in bare-root seedlings was not strong enough to reach 
the primary meristem and make nutrients and water available for the production of new leaves. In contrast, rootstock with a smaller distance for water and nutrients to travel were able to have a mean leaf number almost twice that of the bare-root (Figure 3), in the peak of leaf bearing in the growing season. As winter approached, leaf senescence made the treatments similar for the mean number of leaves by plants between treatments.

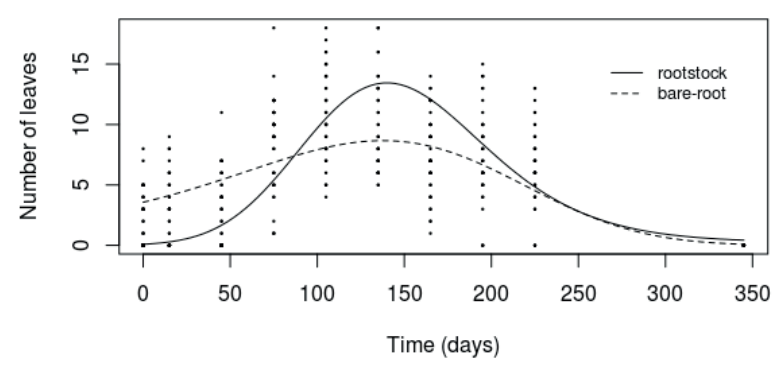

FIGURE 3 Mean number of leaves by plant in each treatment during the first growing season after planting of $C$. fissilis seedlings lifted from natural regeneration in nearby forests.).

Seedlings had a large variation among themselves regarding height increment. For this reason, a hierarchy was used to explain treatment effect on height. In addition, we observed negative increment between measurements in several occasions (Figure 4). This is a common feature in time series data (CLARK; BJORNSTAD 2004; CLARK et al. 2007) when the observations are too close in time between them. It has been recommended that the observations which represent negative increments should be excluded from the data (CLARK; CLARK 1999; CLARK et al. 2007). However, we believe that measurement errors have the same probability of overestimate or underestimating increment, as long as the observations are independent. Our measurements were made in the field with no knowledge of the results of the previous measurement, so that they were totally unbiased. Thus, we did not exclude any observation, and expected the mean tendency to be the best estimation of the true value of height increment in any given time span.

The exploratory analysis of the data already shows a large difference between height increments of the treated and untreated seedlings. While rootstock $C$. fissilis grew almost $60 \mathrm{~cm}$ in height over a year, bare-root seedlings grew no more than $15 \mathrm{~cm}$. Our model showed that RCD, time and treatment affected height growth (Figure 5). Rootstock seedlings grew $14 \mathrm{~cm}$ more per unit diameter over a year than did untreated plants. Furthermore, initial RCD had a larger effect on growth of treated seedlings $(1.4 \mathrm{~cm} / \mathrm{cm})$ than in bare-root seedlings $(0.04 \mathrm{~cm} / \mathrm{cm})$. Initial RCD had a large effect due to more carbohydrate reserves in the remaining roots and stem of rootstock seedlings, enabling plants to have a more vigorous and balanced sprouting and leaf formation (LANDHAUSSER et al. 20I2; ZHU et al. 20I2). In the bare-root seedlings this effect was smaller because larger seedlings had a larger stem and therefore higher evapotranspiration, eliminating any advantage that larger carbohydrate reserves could have. Reserves in the bare-root seedlings were probably used to develop roots as a way to re-balance the S:R (DESROCHERS; TREMBLAY, 2009).

Large seedlings of $C$ fissilis have a higher survival rate and a larger increment. However, producing larger seedlings is more expensive (SOUTH et al., 200I; WATSON, 2005). One inexpensive source of large seedlings is the use of regenerating saplings from natural forests. However, these seedlings are adapted to forest

A

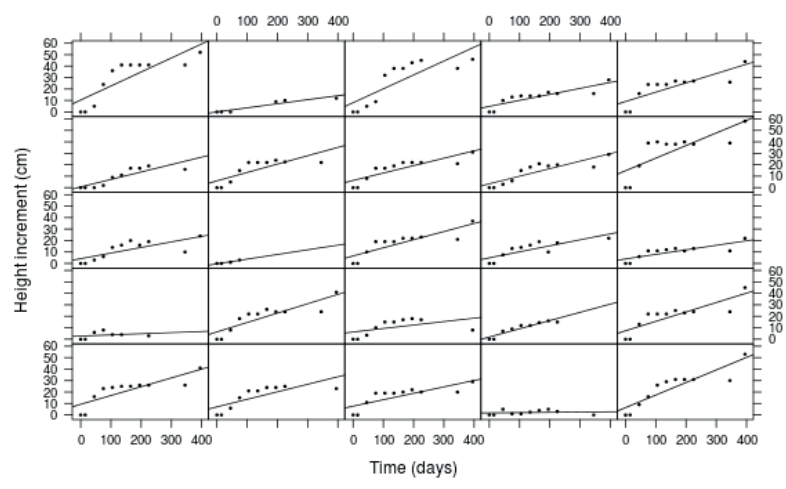

B

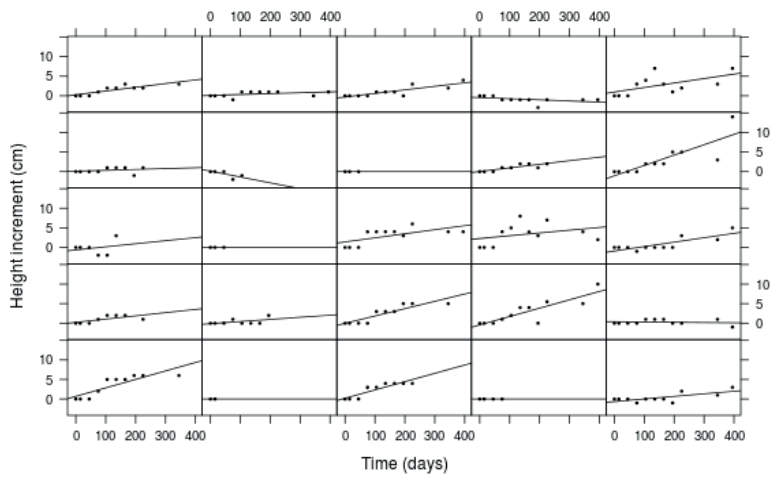

FIGURE 4 Observed heights and mean individual linear tendencies along time for rootstock (a) and bareroot (b) seedlings of $C$. fissilis, lifted from natural regeneration of a nearby natural forest in Santa Maria, Brazil. 


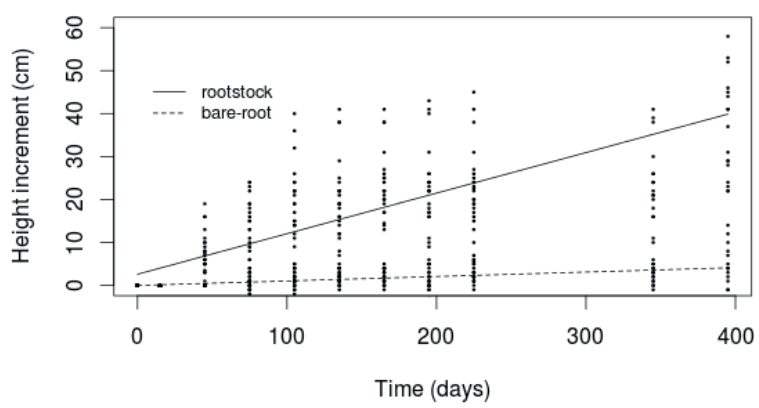

FIGURE 5 Mean height growth of treated and untreated seedlings of $C$. fissilis in southern Brazil.

conditions and do not thrive in open field plantings. This is due to high development of the shoot system in the search for light, and low development of the root system in a variation of the forest floor which is relatively rich in nutrients and has low water availability. However, by shoot pruning these saplings we were able to produce rootstock seedlings with high survival rates and growth. The use of saplings from natural forests may deplete regeneration in natural forest (KETTLE, 2009), but new areas of regeneration of the collected species will be created. Therefore, we believe that the techniques here described should be of great help for any project that aims to plant trees of native species with sprouting ability.

\section{CONCLUSIONS}

Seedling survival was higher for plants under the rootstock method, especially for saplings with rootcollar diameter larger than $1 \mathrm{~cm}$.

Bare-root seedlings had a higher number of leaves at the beginning of the experiment, but rootstock seedlings quickly developed larger and deeper crowns than the former.

Height growth had high variability, but rootstock seedlings grew much faster and had a mean height increment of $60 \mathrm{~cm}$ over a full growing season.

\section{REFERENCES}

BIRCH,J. C., NEWTON, A. C., AQUINO, C. A., CANTARELLO, E., ECHEVERRIA, C., KITZBERGER, T., SCHIAPPACASSE, I. E GARAVITO, N. T. Cost-effectiveness of dryland forest restoration evaluated by spatial analysis of ecosystem services. Proceedings of the National Academy of Sciences, v. 107, n. 50, p. 21925-21930, 2010.

BORCHERT, R. TOMLINSON, P. Architecture and Crown Geometry in Tabebuia rosea (Bignoniaceae). American Journal of Botany, v. 7I, n. 7, p. 958, 1984.
CAMPOE, O. C., IANNELLI, C., STAPE, J. L., COOK, R. L., MENDES, J. C. T. and VIVIAN, R. Atlantic forest tree species responses to silvicultural practices in a degraded pasture restoration plantation: From leaf physiology to survival and initial growth. Forest Ecology and Management, v. 3 I3, p. 233-242, 2014.

CAMPOE, O.; STAPE, J.; MENDES, J. Can intensive management accelerate the restoration of Brazil's Atlantic forests?. Forest Ecology and Management, v. 259, n. 9, p. $|808-| 8 \mid 4,2010$.

CHAZDON, R. Beyond Deforestation: Restoring Forests and Ecosystem Services on Degraded Lands. Science, v. 320, n. 5882, p. |458-|460, 2008.

CLARK, D. A. AND CLARK, D. B. Assessing the growth of tropical rain forest trees: issues for forest modeling and management. Ecological Applications, v. 9, n. 3, p. 98I-997, 1999.

CLARK, J.; BJØRNSTAD, O. Population time series: process variability, observation errors, missing values, lags, and hidden states. Ecology, v. 85, n. II, p. 3|40-3 I50, 2004.

CLARK, J. S.; WOLOSIN, M.; DIETZE, M.; IBÁÑEZ, I.;LADEAU, S.; WELSH, M. E.; KLOEPPEL, B. Tree growth inference and prediction from diameter censuses and ring widths. Ecological Applications, v. 17, n. 7, p. 1942-1953, 2007.

DALMOLIN R.S.D.; PEDRON F. A. Solos do município de Santa Maria. Ciência \& Ambiente. 38:59-78, 2009.

DESROCHERS, A.; TREMBLAY F. The effect of root and shoot pruning on early growth of hybrid poplars. Forest Ecology and Management. 258:2062-2067, 2009.

DONOSO, P.; SOTO, D.; GERDING V. Efectos de la poda de tallo y fertilización de liberación controlada en vivero sobre el comportamiento de plántulas de Nothofagus nervosa en terreno. Bosque. 30:48-53, 2009.

Evans, J. Plantation forestry in the tropics. Traducao . Oxford: Clarendon Press, 1992.

GROSSNICKLE, S. C. Why seedlings survive: influence of plant attributes. New Forests. 43:7II-738, 2012

HARRISON, S.; GREGORIO, N.; HERBOHN, J. A Critical Overview of Forestry Seedling Production Policies and Practices in Relation to Smallholder Forestry in Developing Countries. Small-scale Forestry. 7:207-223, 2008.

HELDWEIN,A.B.; BURIOL, G. A.; STRECK, N. A. O clima de Santa Maria. Ciência \& Ambiente 38:43-58, 2009.

HODGE, A.; BERTA, G.; DOUSSAN, C.; MERCHAN, F. E.; CRESPI, M. Plant root growth, architecture and function. Plant Soil, v. 321, n. I-2, p. I53-187, 2009.

ICHIWANDI, I., SHINOHARA, T., CHEN, B. An assessment of teak planting under tumpangsari system in Cepu Forest District, Central Java, Indonesia. Science Bulletin of the Faculty of Agriculture 56:33-4I, 2009. 
KETTLE, C. J. Ecological considerations for using dipterocarps for restoration of lowland rainforest in SOUTHeast Asia. Biodiversity and Conservation. 19:1।37-1 I5I, 2009.

LANDHAUSSER, S.M.; PINNO, B. D.; LIEFFERS, V. J.; CHOW, P. S. Partitioning of carbon allocation to reserves or growth determines future performance of aspen seedlings. Forest Ecology and Management. 275:43-5I, 2012.

MCNABB, K.; SCHAAF, C. Growth of graded sweetgum 3 years after root and shoot pruning. New For. 29:313320, 2005.

NAVARRO-CERRILLO, R. M.; GRIFFITH, D. M.; RAMÍREZSORIA, M. J.; PARIONA, W.; GOLICHER, D. AND PALACIOS, G. Enrichment of big-leaf mahogany (Swietenia macrophylla King) in logging gaps in Bolivia: The effects of planting method and silvicultural treatments on longterm seedling survival and growth. Forest Ecology and Management. 262:227I-2280, 201 I.

R CORE TEAM (20I3) R: a language and environment for statistical computing [Internet]. Vienna (Austria): R Foundation for Statistical Computing.

SCHWARTZ, G.; LOPES, J. C. A.; MOHREN, G. M. J., PEÑACLAROS, M. Post-harvesting silvicultural treatments in logging gaps: A comparison between enrichment planting and tending of natural regeneration. Forest Ecology and Management. 293:57-64, 2013.

SIDHU, D. S; DHILLON, G. P. S. Field performance of ten clones and two sizes of planting stock of Populus deltoides on the Indo-gangetic plains of India. New For. 34: I I 5-122, 2007.

SMITH, J. R. C. E. A revision of Cedrela (Meliaceae). Fieldiana. 29:295-34I, 1960.

SOUTH, D. Top-pruning bareroot hardwoods: a review of the literature. Tree Plant Notes. 47:34-40, 1996.
SOUTH, D.; DONALDA, D. Effect of nursery conditioning treatments and fall fertilization on survival and early growth of Pinus taeda seedlings in Alabama, USA. Canadian Journal of Forest Research. 32:1171II79, 2002.

SOUTH, D. B.; RAKESTRAW, J. L.; LOWERTS, G. A. Early gains from planting large-diameter seedlings and intensive management are additive for loblolly pine. New Forests. 22:97-II0, 2001 .

VIANI, R.; RODRIGUES, R. Potential of the seedling community of a forest fragment for tropical forest restoration. Science and Agriculture. 66:772-779, 2009.

VIANI, R. A. G.; BRANCALION, P. H. S.; RODRIGUES, R. R. Corte foliar e tempo de transplantio para $\circ$ uso de plântulas do sub-bosque na restauração florestal. Árvore $36: 33 I-339,20 I 2$.

WATSON, W. Influence of tree size on transplant establishment and growth. Horticulture and Technology. 15:1 I8122, 2005.

YOSHIMURA, K. Irradiance heterogeneity within crown affects photosynthetic capacity and nitrogen distribution of leaves in Cedrela sinensis. Plant, Cell \& Environment. 33:750-8, 2010.

ZHU, W. Z.; XIANG, J. S.; WANG, S. G., LI, M. H. Resprouting ability and mobile carbohydrate reserves in an oak shrubland decline with increasing elevation on the eastern edge of the Qinghai-Tibet Plateau. Forest Ecology and Management. 278: II8-126, 2012.

ZIMMERMANN MH, BROWN CL (197I) Trees: structure and function. New York, USA, Springer-Verlag. 
